\title{
Ditching Dewey and developing a love of reading
}

\author{
Sally Cameron \\ Marymount International School \\ Marymount International School, Via 191, \\ Roma, Italy \\ scameron@marymountrome.it
}

\begin{abstract}
This short professional paper takes a look at how I developed a love of reading by removing the Dewey Decimal system from the school library. I detail how I came to the decision, the process I followed and how the library is arranged and used today. There is also reference to other practices that have encouraged life-long readers, such as removal of all reading "incentives", parent helpers, and ways to encourage families to use the library.

The actual presentation of this paper is in the form of a slideshow. There will be talking, but every stage of the process and the ideas shared have pictures to go with them. Come and see it!
\end{abstract}

Keywords: Reading promotion, Dewey Decimal System

\section{Introduction}

First, let me tell you about my school. Marymount International is a set in 40 acres of national park on the northern outskirts of Rome. It is both beautiful and wonderful.

The school was founded in 1946 by the Religious of the Sacred Heart of Mary to educate the children of allied troops and personnel stationed in Rome after WW2. Today the school has taken students at age three and sees many of them through their IB examinations. Students at the school currently represent more than 60 countries and while the school is a catholic school, all faiths are accepted.

\section{The room of books}

The school has two libraries, one that serves the secondary school and one that serves the elementary.

When I took over the elementary school library in 2007 it was a room of books. Students came, enjoyed a story and then chose a book to take home. Choosing the books was difficult, students didn't seem to have an idea of what they wanted and were quite apathetic about looking for books.

Now I should probably tell you about me. I am not a librarian. I was a teacher at the school, an early childhood specialist, who had been begging to be moved to the library. The librarian was begging to move to be a classroom teacher. Finally all the pieces fell into place and we swapped. So, as I looked at the children and their lack of enthusiasm, I looked at them as a teacher would. 
What I noticed was this: the picture books were on the shelves in alphabetical order, spines out. It was difficult to see where the letters began and ended, so my first move was to get a label for every shelf so it was easy to see where all the "a" books were, etc.

The following week, the children were very excited to see the labels, but were still not much more interested in the books. I thought that maybe if they helped me put some books away they would be enticed by those books, picking up things they hadn't tried before. It didn't work and the main outcome of that exercise was that I spent a day reordering the shelves.

\section{Dewey must go}

As I reordered the shelves it began to dawn on me that most of these students, aged $5-11$, couldn't put books in order. While the older students were more able, the younger ones could not. Taking a look at the standards and benchmarks for the school, which ring true even today, children learn the alphabet in Kindergarten, they use beginner dictionaries in grade $2^{*}$, but the three-letter alphabetical order knowledge needed to re-shelve or find books is much more complicated than beginner dictionary, and not something that is required of students until they are in fourth or fifth grade. My whole library was organized to be easy for adults and two of the six grade levels that use it.

I decided the most sensible thing to do would be to ask the children how I could help them enjoy the library more. They were pleasantly surprised to have this kind of input and said they wanted to find books quickly, seeing the cover would be helpful, and have a nice place to sit and read them.

I decided on drastic measures. I talked to the teachers and told them I had a new plan for the library but I needed funds. So, they all agreed to bake and we had a cake sale for the library. We raised close to $€ 400$ and I dashed off to lkea and spent it all on containers, rugs and cushions.

The first step in the process was sorting through the books. I had a serious weeding session, and got rid of over 1000 books. By then it was 2009 and I felt that no library needed to have a copy of "George Washington Carver, Negro Scientist" on the shelf. The students helped, the older ones were particularly good at finding old looking books, and we looked them up to see when they had last been checked out, if it was more than 3 years, the book went. If it was less than that, but looked awful we got rid of it and I replaced it. A good proportion of the books were sent to be recycled, but many were put out on the window ledge with a sign inviting students to give the books a good home. All were taken.

\section{A slight tangent}

At this point we must digress a little. It was around this time that a parent came to volunteer to help me in the library. She brought a friend, who brought a friend and they came every week. In fact, they came for a whole day every week. The small group grew and they began to bring lunch with them. We would eat together and share our meals. Thursdays were Library Day. I got so much done having this amazing team helping me. They cleaned, they catalogued, they put stickers on books, they labelled and repaired and became experts with contact paper... The trick was the lunchtime. It was their time. The social aspect of it made it work. We would share our food, so you'd have a lunch of homemade sushi, Egyptian mince, 
Danish bread and Italian cold cuts. One of the parents stood up at the meeting to welcome new families and told them that volunteering to work in the library was the best thing she had done, not only was she helping the school but she had made a wonderful network of friends from all around the world.

The group is still going today, none of the original members remain and sometimes the group is smaller than others, but I still have help. Make it a time for them too, have them teach each other a new task - have a cataloguing expert and pair them up with the new parent who prefers computer work to re-shelving. It really works.

\section{Back to the picture books}

As the space cleared and I could finally see what I was working with I decided that the best place to go next was designating major authors a box each, followed by favorite characters, and then various topics. For example, there were boxes for Mem Fox, Tomie DePoala, Dr Seuss, Dora \& Diego, Star Wars, Clifford, Dinosaurs, Families and Inventions.

Each box had a label and the books went in the box. There was a matching label on the shelf so that they children could take the box down and walk off with it, to a comfortable place where they could look through the box. It was then very easy for them to replace the box in the right place. The books in each box had the name of the box written on the back (thank you volunteer Mummies!) next to the barcode.

Think for a minute about how that revolutionizes your re-shelving. The book needs dropping into a box, anywhere in the box will do. Give a Kindergartener a handful of Star Wars books and ask them to put the books away, and they can. In the right place too!

\section{Non-fiction books}

To my delight, the older students were now using the picture book section as much as the rest of the library. They loved the layout, and asked if we could do the same for the nonfiction books and novels. So I began the process again with them. The observation previously made about teaching alphabetical order is reflected when we talk about hundreds and decimals. Beginning in grade two**, students are being taught to compare two threedigit numbers and say which is < or $>$, actual decimals are not taught until grade five. The library system was not age-appropriate for my students.

We weeded and sorted and labelled as before. Along with the students I decided to put all of Ancient Egypt in one box, all the art, technology, math, and history all in one box, so everything is in one place. We followed this example for all major social studies topics. The students loved it and so did the teachers.

In case you are wondering, ditching Dewey has not been a problem for the students as they move on to the secondary school library. They are familiar with decimals by then and able to manipulate larger numbers almost without thinking, and they learn the system in no time at all.

\section{The genrefication of chapter books}


When it came to the novels, the students told me that they liked certain kinds of books and it would be good to have all those kinds of books together in one place. So, we set about organizing the books into genre. They had a great time doing this, reading the back of the book to see what it was about and making a decision about where it went.

One day a student came to me with a Roald Dahl book and said, "I'm confused. This book is really funny, but there are talking animals in it, and there is a sort of mystery too. I don't know where to put it." I called the class together and we talked through the problem together and a student suggested that, as many of his books could not be sorted into one genre, maybe Roald Dahl should have a shelf of his own. And so the author shelves were born.

We collected the books by their favorite authors and shelved them together. Each author has their own section and their shelf-label also includes a couple of facts about them.

Now, they have read so much of what they like that when they re-shelve they do sit down and try something new.

\section{Other sections}

Some special areas we have are: books in other languages, which is important for new students coming in who do not speak much English, they can still choose books at their reading level in their language. This section relies a lot on parent donations due to the expense of books in other languages, but we are slowly building up a good collection. Another special area we have is our Global Calendar section. Our school selects a UN day each month to celebrate and there is a box for the most often selected days, such as: World Human Rights Day, International Day of Peace, International Mother Earth Day, etc. Partner Books is the section of the library where pairs of books live. We have discovered that children love to read books together, teachers send students down for partner books. They read the same book, agreeing how much they will read each day and talk about it, like a mini book club. This has branched out from a structured thing, initiated by teachers, to students coming and asking for partner books to read for fun. They are learning to love talking about what they are reading, sharing their ideas and arguing their point of view. I have now begun to order second, or third copies of the most popular books to keep this section going.

\section{Independence}

Not only can the students independently find books and out books away, they can check them out too.

The scanner. The Holy Grail of library equipment, the much desired laser of power that the children dream of... I set up a computer for check-out and the children do it themselves. This must be the most popular thing ever! I have a book of student barcodes ordered by homeroom. They scan their code and then the book. They LOVE it! I spent the first two weeks teaching them how to do this, how to use the scanner safely, how to replace it properly in the cradle. We practice and they learn it quickly. By the end of the third visit the Kindergarteners can check out their own books. This frees me up to be talking to students about what they are looking for, or finding a new author for them to read. They know when to call me for help, and when to click "yes" and carry on. I would highly recommend letting go of the scanner.

\section{Ownership}


As this system was being used by the children I noticed two main things. Firstly the students were much more interested in the books. They were asking for authors and series by name and asking to check out more than one book at a time, more parents were coming in because their child had been talking about the library. Secondly, the students were gaining ownership of their library. They could find books and make informed selections, they could put books away and take care of the space. They had been heard; the library was theirs.

I cannot underline enough the importance of their feedback, asking for it and acting on it. Last year we were rearranging the library, our plan was to move the computer lab down into the library, so the computer teacher and I could co-teach. Without telling the students our plans, I asked them what change they would make. Younger students wanted more sofas and chairs so they could sit together and read, older students wanted more "secret" cubby holes and dens where they could go and read with a friend or two. Many mentioned moving the computers, so they were delighted to discover that was happening!

Our students feel like they own the library, it is theirs and they love to be there. I have a suggestion book on my desk where students, and parents, are invited to write suggestions they request books or suggest new layouts, offer new ideas. This is what makes the library successful, having them understand that the library is not mine, it is ours.

\section{Developing a love of reading}

\section{No reading incentives}

It took a while to convince some teachers, but I do not endorse any kind of reading incentives. I got rid of the Reading Counts program when students would only read books they could do a quiz on. I object strongly to these quizzes, firstly because knowing the name of the author (always the first question of ten about the book) has nothing to do with comprehending the book and because they give children the idea that there is a right or wrong answer to a book. I refuse to have this in the library. Your response to the book you have read is yours, and as long as you can defend it is always right.

We do not have reading competitions, or Accelerated Reader programs because research shows that children only read until they win or finish, they do not carry on reading afterwards (links to articles about this below). You cannot foster a love of reading in this way.

I ditched the reading games and competitions and now have students who really enjoy reading for the sake of enjoying reading. The reward for finishing a book, or for deciding that you don't want to finish the one you are reading, is that you can start a new one. It is that simple.

\section{The Reader's Bill of Rights by Daniel Pennac}

This hangs on the library door.

1. The right to not read

2. The right to skip pages

3. The right to not finish

4. The right to reread

5. The right to read anything

6. The right to escapism 
7. The right to read anywhere

8. The right to browse

9. The right to read out loud

10. The right to not defend your tastes"

It can be controversial and some parents don't like that their children have "The right to read anything" when their child has been seduced by Captain Underpants and Goosebumps, but I stand by this bill of rights and it gives children the courage to read as they want to. It empowers them to make choices about their reading, which is exactly what they should be doing. A recent article in the Washington Post discussed research findings that "middle and high school students who have time to read books of their own choosing during the school day are also more likely to read frequently for pleasure." (Link to full article below). So shouldn't we be teaching and allowing our students to do this as soon as possible? Making it second nature for them?

\section{The Library Challenge}

Each week I post a question and the students use the resources in the library to answer it. They get a point for a correct answer that has the reference cited. No cite, no point! When they have 5 points they can choose a free book from the Scholastic Magazine, I use points for the books. The challenge questions are always two step questions and some examples are, "What is an Akita and what is it commonly used for?", "What might you see coming from an embrasure?", "What is the name of the currency used in Africa's smallest country?", "What do you get if you multiply all the numbers on a telephone together?".

The challenge is for fun, no-one is required to take part. It appeals to my nerdier and geekier students, and a lot of boys. The answer is posted in detail so they can read up about it if they didn't get it right. It gives students who are not enthusiastic readers another reason to enjoy being in the library, and they get to choose a book for their efforts.

\section{Welcome Baby}

I used some Scholastic magazine points to buy board books. When a student has a new addition to their family they come and choose a book for their baby. I put a book-plate saying that the book is a gift to the baby from the school, and we hope they will grow to love reading as much as we do.

This tiny thing has a big impact. Students get extra recognition and attention when a new baby is born, they are excited about choosing a present for the sibling. Parents love that their child is bringing home a gift for the baby, and many report that the older child love to read that book to the baby often. If the baby has two siblings in school, they get two books, each sibling chooses one.

\section{Rise and Read}

There may be times that you wonder why on earth you began something as crazy as Rise and Read. You need to push on through that because it is wonderful. Rise and Read takes place every month (I began weekly, you pace yourself as you need to!). The library is open to everyone from 7:45 until the school bell rings. Families are invited to come and read together before school. Parents can read their newspapers, books and kindles while children read theirs, or parents can read to their children. I supply tea, coffee and juice; the PTO supplies cookies or cake. Books and Breakfast - probably the best combination in the world. Children spring out of bed and are dressed in minutes when we have Rise and Read, I see 
parents that I didn't know existed, grandparents too. Teachers come down and read, parents stay after the bell and browse through the books. All siblings are invited. It's messy, but it is lovely. There is a wonderful sense of community. Books are being loved, read and shared. It brings whole families into your library, what's not to love?

\section{References}

Common core standards and UK national curriculum

Common Core: Literacy * http://www.corestandards.org/ELA-Literacy/L/3/

National Curriculum: English

*https://www.gov.uk/government/uploads/system/uploads/attachment data/file/335 186/PRIMARY national curriculum - English 220714.pdf

Common Core: Math

${ }^{* *}$ http://www.corestandards.org/Math/Content/2/NBT/

\section{Articles about reading incentives}

A Closer Look at Reading Incentive Programs By Alfie Kohn http://www.alfiekohn.org/teaching/readingincentives.htm

Summer Reading Incentives Positive or Pernicious? Suzanne M. Stauffer https://resources.oncourse.iu.edu/access/content/group/6eed208c-bc4b-4658ab506c9ee012c201/Public\%20Library\%20Services/Week\%206/Summer\%20Reading\% 20Incentives.pdf

Creating Readers: A Case Against Extrinsic Rewards By Angela Bunyi http://www.scholastic.com/teachers/post/creating-readers-case-against-extrinsicrewards

The Reader's Bill Of Rights http://www.goodreads.com/quotes/19297-reader-s-bill-of-rights-1-the-right-to-notread

Washington Post Article http://www.washingtonpost.com/blogs/wonkblog/wp/2015/01/10/if-we-stop-tellingkids-what-to-read-they-might-start-reading-again/ 